SANDIA REPORT

SAND 2005-4357

Unlimited Release

Printed July 2005

\title{
Sandia National Laboratories, California Pollution Prevention Annual Program Report for Calendar Year 2005
}

\author{
L. J. Farren
}

\section{Source Reduction}

Prepared by

Sandia National Laboratories

Livermore, California 94550

Sandia is a multiprogram laboratory operated by Sandia Corporation,

a Lockheed Martin Company, for the United States Department of

Energy under Contract DE-AC04-94AL85000.

Approval for public release pending

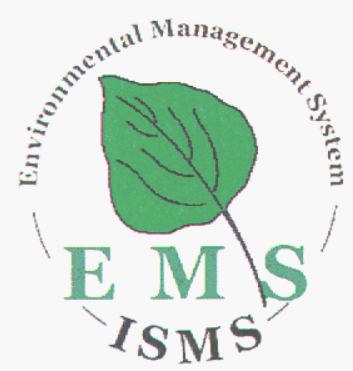


Issued by Sandia National Laboratories, operated for the United States Department of Energy by Sandia Corporation.

NOTICE: This report was prepared as an account of work sponsored by an agency of the United States Government. Neither the United States Government, nor any agency thereof, nor any of their employees, nor any of their contractors, subcontractors, or their employees, make any warranty, express or implied, or assume any legal liability or responsibility for the accuracy, completeness, or usefulness of any information, apparatus, product, or process disclosed, or represent that its use would not infringe privately owned rights. Reference herein to any specific commercial product, process, or service by trade name, trademark, manufacturer, or otherwise, does not necessarily constitute or imply its endorsement, recommendation, or favoring by the United States Government, any agency thereof, or any of their contractors or subcontractors. The views and opinions expressed herein do not necessarily state or reflect those of the United States Government, any agency thereof, or any of their contractors.

Printed in the United States of America. This report has been reproduced directly from the best available copy.

Available to DOE and DOE contractors from

U.S. Department of Energy

Office of Scientific and Technical Information

P.O. Box 62

Oak Ridge, TN 37831

Telephone: (865) 576-8401

Facsimile: (865) $576-5728$

E-Mail: $\quad$ reports $\quad$ a adonis.ostigov

Online ordering: http://www.doe gov bridge

Available to the public from

U.S. Department of Commerce

National Technical Information Service

5285 Port Royal Road

Springfield, VA 22161

Telephone:

(800) 553-6847

Facsimile: (703) 605-6900

E-Mail: $\quad$ orders antis.fedworld.gov

Online order: http://www.ntis.gov/ordering.htm
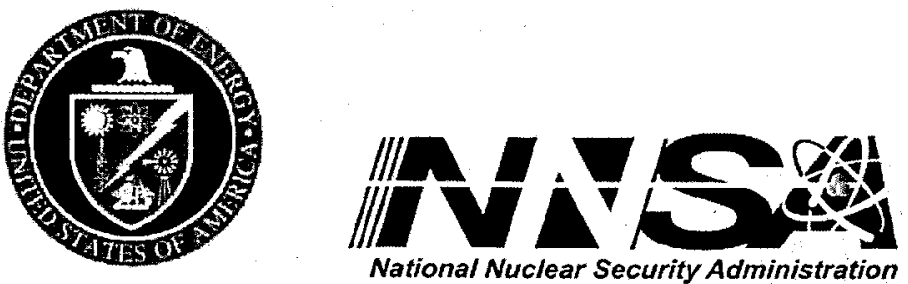


\title{
Sandia National Laboratories, California Pollution Prevention Annual Program Report for Calendar Year 2005
}

\author{
Laurie J. Farren \\ Environmental Management Department \\ Sandia National Laboratories, California
}

\begin{abstract}
The annual program report provides detailed information about all aspects of the SNL/CA Pollution Prevention Program for a given calendar year. It functions as supporting documentation to the SNL/CA Environmental Management System Program Manual. The 2005 program report describes the activities undertaken during the past year, and activities planned in future years to implement the Pollution Prevention Program, one of six programs that supports environmental management at SNL/CA.
\end{abstract}




\section{Contents}

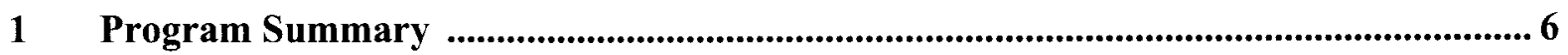

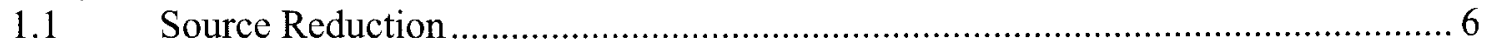

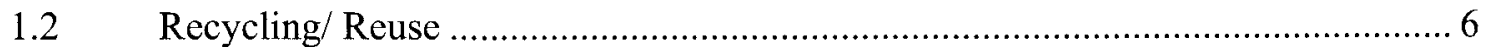

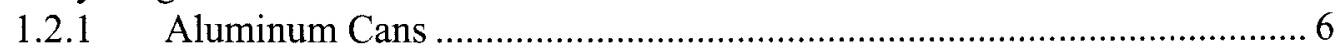

1.2.2 Asphalt/Concrete/Construction Debris .......................................... 7

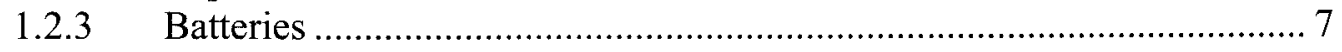

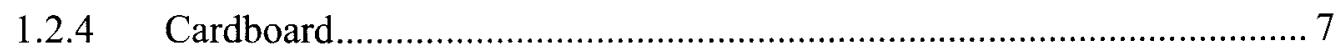

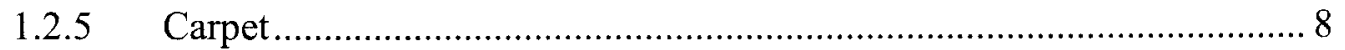

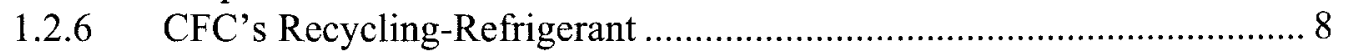

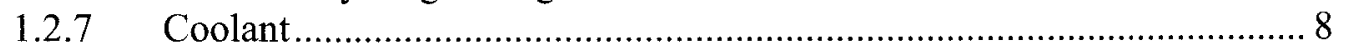

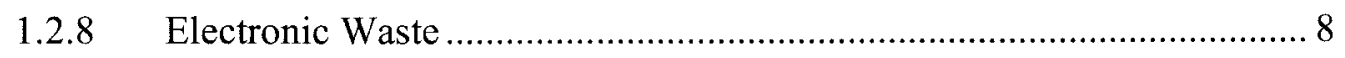

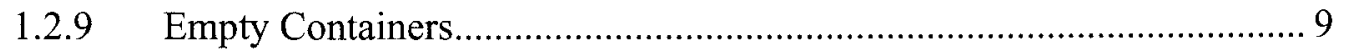

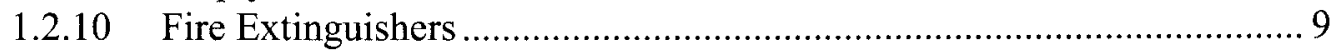

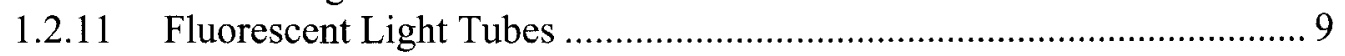

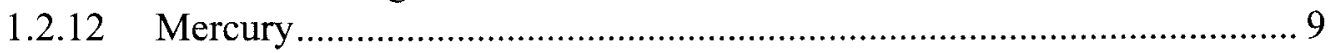

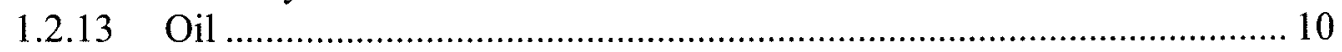

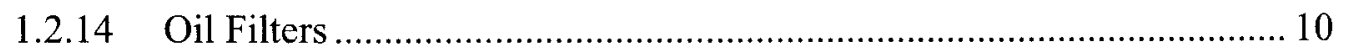

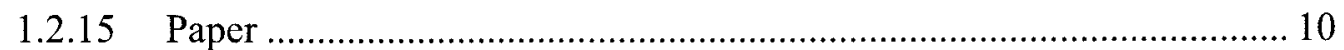

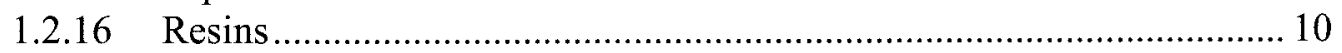

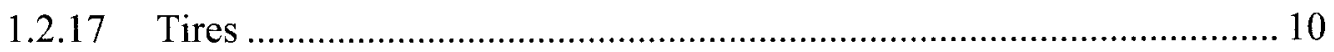

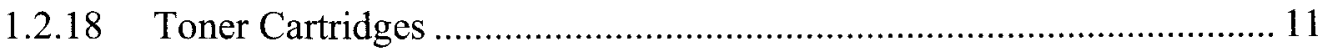

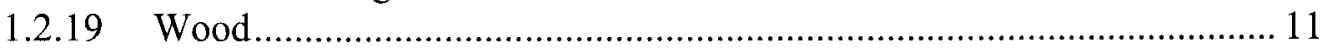

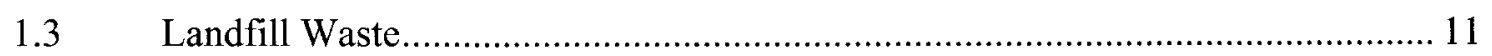

1.4 Pollution Prevention Opportunity Assessments (PPOA) .................................. 12

1.5 Affirmative Procurement ................................................................. 12

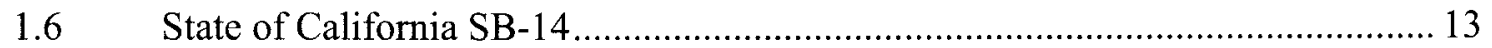

1.7 Waste Information Management System (WIMS) ..................................... 13

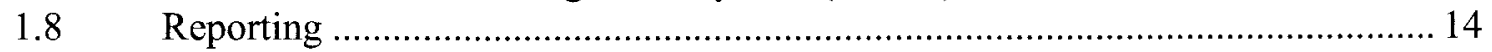

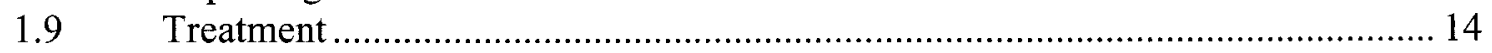

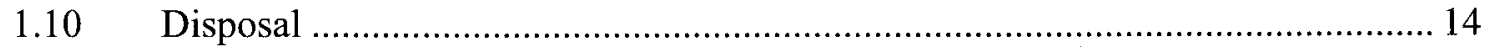

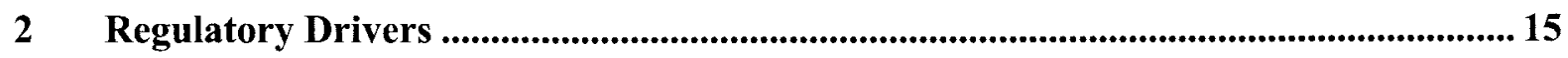

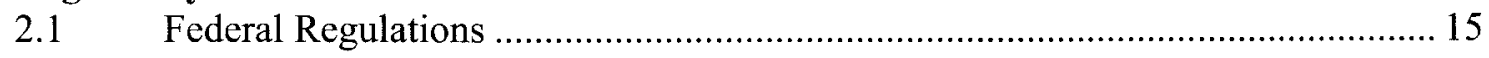

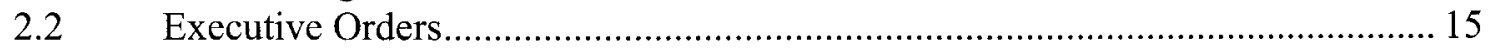

2.3 Department of Energy Requirements.................................................. 16

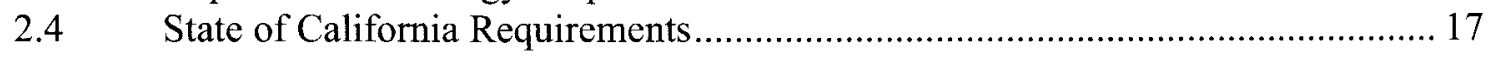

$3 \quad$ Operations Controls .................................................................................................................18

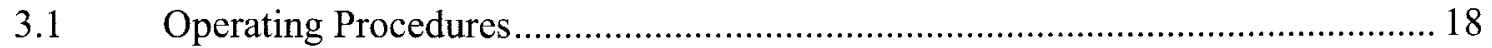

Interdisciplinary Team (IDT) Review ................................................. 18 
4 Documents Produced ..................................................................................................... 19

$5 \quad$ Approved Job Descriptions, Qualifications, and Training .......................................... 20

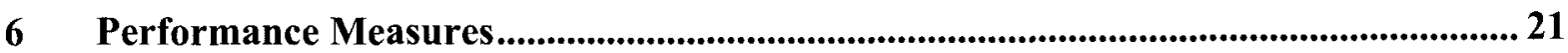

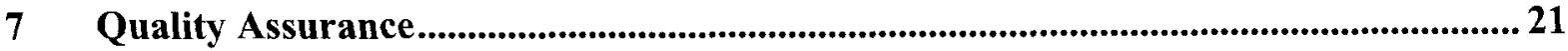

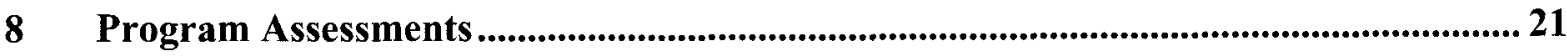

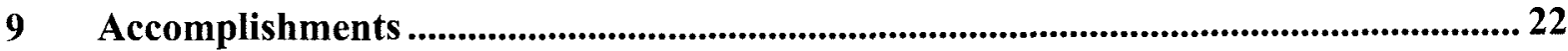

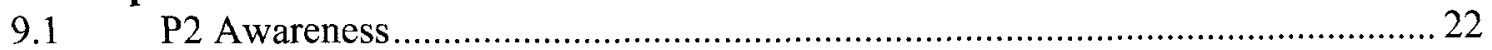

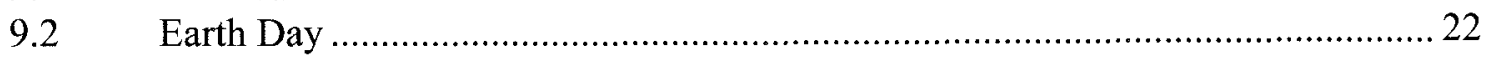

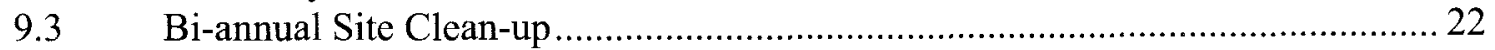

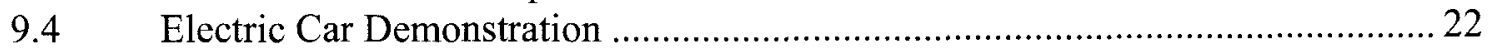

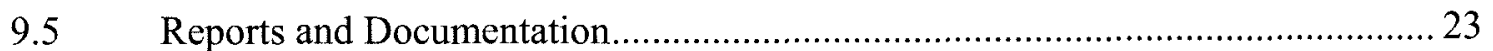

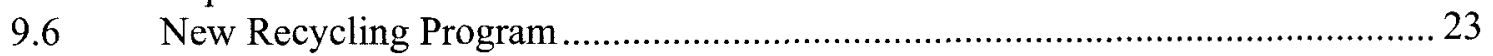

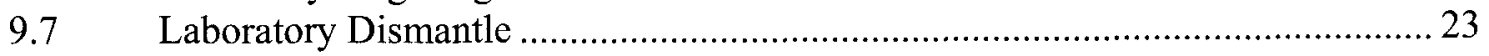

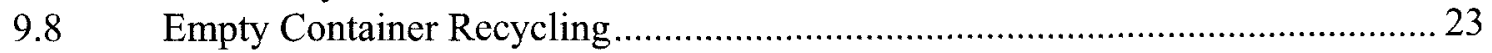

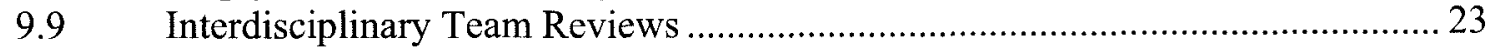

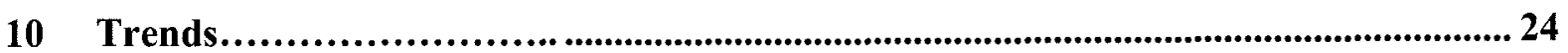

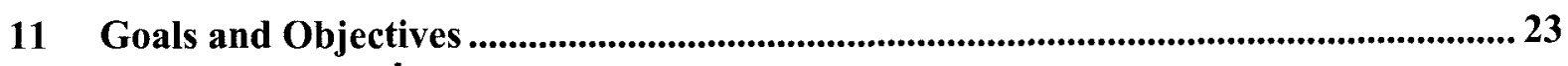

\section{Figures}

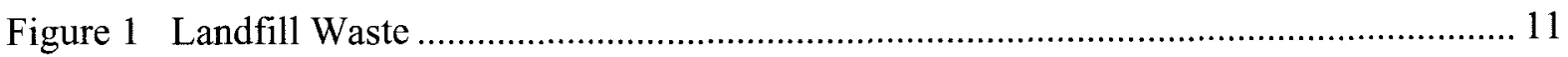

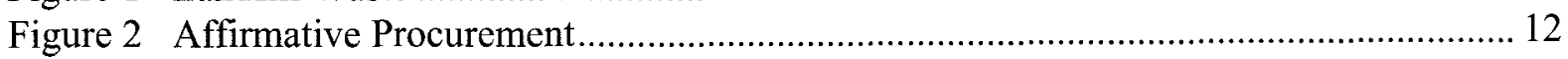

Figure 3 Routine Hazardous Waste ...................................................................... 14

\section{Tables}

Table 1 P2 Reporting Categories ........................................................................ 13

Table 2 Pollution Prevention Program Documents and Reports ....................................... 19

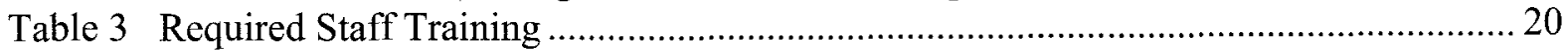

\section{Appendices}

Appendix A P2 Program Self-Assessment Document Review Form.......................26

Appendix B Current Program Staff Assignments.....................................27 


\section{Program Summary}

Pollution Prevention (P2) is one of six environmental programs under the Environmental Management Department at Sandia National Laboratories/California (SNL/CA). This multitasked program applies to any activity that generates waste and uses resources. Pollution Prevention is an important environmental management tool, and provides a means of reducing waste, and saving resources which results in economic benefits, enhanced public image, and reduced environmental risk. By implementing source reduction, waste minimization measures and recycling, Sandia reduces volume and toxicity of waste generated.

The purpose of the $\mathrm{P} 2$ program is to provide SNL/CA with technical assistance and strategies for reducing the generation of waste and use of our natural resources. It also manages the site's recycling programs, Pollution Prevention is a requirement of Federal, State and local regulations. The Pollution Prevention program is directly funded by the Department of Energy for this specific task.

\section{$1.1 \quad$ Source Reduction}

Source reduction is the prevention of waste generation achieved by affecting the source of its generation. Source reduction is always the preferred option for waste reduction. Site activities that contribute to source reduction include: 1) P2 participation during project and activity planning, 2) the review of waste generation processes through formal Pollution Prevention Opportunity Assessments, 3) awareness campaigns and 4) training. Pollution Prevention information is provided to each new hire and source reduction measures are included in Waste Generator training.

\section{$1.2 \quad$ Recycling/Reuse}

Recycling/reuse is the recovery of materials from a solid waste stream for use as either raw material in the manufacturing of new products or for direct reapplication. Recycling/reuse is considered to be the second preferred option after source reduction. Currently SNL/CA has 19 different recycling/reuse streams. The coordination of these recycling/reuse streams is continually fine tuned and new streams are added when applicable. The recycling/reuse programs are managed by the P2 Program Leads with specific data collection and transportation of the various recycling streams the responsibility of Property Reapplication and the Facilities Maintenance departments.

The following recycling/reuse processes are currently in use at SNL/CA:

\subsubsection{Aluminum Cans}

The aluminum can is the most valuable beverage container to recycle and it is the most recycled consumer product in the U.S. Recycling aluminum cans provides environmental, economic and community benefits. At SNL/CA this waste stream is generated from onsite consumption of beverages. Recycling bins for collection are placed at various points around the site and the cans 
are collected by the Maintenance Department. These are then provided to a contract recycler who pays SNL/CA. Receipts are provided for required data reporting. Funds generated from this recycling program are provided to the Holiday Spirit Grocery and Gift Campaign at the end of the calendar year.

\subsubsection{Asphalt/Concrete/Construction Debris}

The use of recycled aggregate can save money, create business opportunities, saves energy when the recycling is done onsite, and conserves diminishing resource of urban aggregate. At SNL/CA this waste stream is generated from in-house and contracted construction and demolition projects. Materials crushed onsite are redistributed on roads or hauled to a permitted facility for reuse.

Contracted construction debris is typically managed by the construction or demolition contractor. The debris is transported to various centers for recycling as prescribed in the construction project specifications. The $\mathrm{P} 2$ program is evaluating the installation of an onsite collection area with the objective of obtaining improved recycling information.

\subsubsection{Batteries}

Battery recycling protects our environment from heavy metal contamination and can reduce the risk of future financial liabilities associated with land disposal. This waste stream is generated from various site use and processes such as: testing activities, automotive repair, alarm systems, two-way radios, pagers and cell phones. All batteries are managed as hazardous waste by the Waste Management program. Non-leaking carbon-zinc, alkaline, lithium and nickel metal hydride batteries are collected via the internal mail. Lead-acid, mercury, and silver oxide batteries as well as any battery that has evidence of leakage are picked up as hazardous waste after the completion of a Waste Description Disposal Request form (WDDR). Batteries are sorted, packed, and sent to a treatment, storage and disposal contractor for either recycling and or disposal. Quantity data is collected by the P2 Coordinator for reporting into the Waste Information Management System.

\subsubsection{Cardboard}

Old corrugated cardboard constitute a significant percentage of landfill waste. This waste stream is generated from packages, packing materials and materials storage. Four cubic yard bins are placed around the site for collection of cardboard. The Janitorial staff flattens and delivers the cardboard to the collection bins. Laborers from the Facilities Maintenance department weigh each bin and transport the bins to a common site location for pick up by the landfill company. Quantity data is provided to the P2 Coordinator for data reporting. At the landfill the cardboard is baled and shipped to a recycler. 


\subsubsection{Carpet}

Carpet is available in two forms; tiles and rolls. Carpet tiles are made primarily for business and industrial use, whereas rolls of carpet are typically applied as household floor coverings. Both types are constructed with face fiber, primary and secondary backing, and an adhesive layer. Both carpet tiles and rolled carpet are used at SNL/CA. Carpet waste is generated from repair and remodeling activities at the site. Guidelines for carpet recycling are provided to project managers during project planning. All waste carpeting is collected and stored on pallets so it will remain clean and dry. It is then transported to a carpet recycler.

\subsubsection{CFC Recycling-Refrigerant}

Chlorofluorocarbons are nontoxic, nonflammable chemicals used in the manufacture of aerosol sprays, foam, and used as refrigerants. This SNL/CA waste stream is generated from site cooling systems such as water coolers, refrigeration units, and building air conditioning equipment. Units containing CFC's are transported to the local landfill where trained technicians remove and recover the refrigerant. The $\mathrm{P} 2$ Coordinator is responsible for completing the Bill of Lading, verifying amount of refrigerant (any unit with more than $5 \mathrm{lbs}$ of CFC must be transported off site as a hazardous material), and retaining transportation records. The SNL/CA Traffic Manager coordinates transportation of any unit containing more than $5 \mathrm{lbs}$ of refrigerant.

\subsubsection{Coolant}

Coolant is generic term used to describe fluids that removes heat from engines and other equipment. The majority of coolant generated at the SNL/CA site is from machine shop operations. Equipment such as lathes and milling machines require metal working fluids. These coolants are collected in 55 gallon drums and are processed for site removal by the Waste Management program. Coolant waste is reprocessed by a contract treatment, storage and disposal contractor.

\subsubsection{Electronic Waste}

Many types of electronic products that are widely used in workplaces and homes contain hazardous lead and mercury. When these products reach the end of their useful lives or become obsolete some contain enough of a hazardous substance to be a hazardous waste. One of the major objectives of the Electronic Waste Recycling Act, as amended, is to establish a new program for consumers and the public to recycle and ensure the safe and environmentally-sound disposal of these electronics. Due to advances in technology, many computer users replace their PC's every 18 months. Many of these computers are sent to third world countries for disassembly causing environmental and health concerns. At the SNL/CA computers and other E-wastes are collected and processed for disposal by the Reclamation Department. E-wastes are palletized and transported to Lawrence Livermore National Laboratories (LLNL). At LLNL hard drives are degaussed, monitors are sold and cell phones and PDF's are destroyed and placed into a scrap hopper. 


\subsubsection{Empty Containers}

Empty containers are generated by processes such as plating operations, solvent cleaning, and photo processing and equipment maintenance. Empty containers, which meet the State of California definition of "empty", are collected for recycling at the Satellite Accumulation Point (SAP). Users are provided with online training (eligibility requirements, checklist \& hypertext link) to correctly manage their empty containers. Containers are marked,"Empty for Recycle" to distinguish recycling containers from hazardous waste. The Waste Management program collects and visually inspects these containers to validate recycling eligibility. Any container deemed not eligible for recycling is left behind and the generator is contacted with further instructions.

The Building 910-Plating Lab staff have the responsibility of collecting, inspecting and placing empty containers from plating operations into their bins. Both bins are locked when containers are not actively being added. The P2 Coordinator weighs and moves the bins, records the data and makes arrangement for pick up.

\subsubsection{Fire Extinguishers}

Most of the fire extinguishers at SNL/CA are portable, dry chemical, self contained, sealed cylinders containing extinguishing agent. Extinguishers are supplied throughout the site for fire suppression and located at the fire yard for fire extinguisher training. Old empty fire extinguishers are sent to a contractor for refurbishment and reuse.

\subsubsection{Fluorescent Light Tubes}

Fluorescent light tubes are one of the most energy efficient lighting sources available. However they contain small amounts of mercury, used to conduct the flow of electric current within the tube. Recycling these tubes offers an environmentally sound alternative to disposal as solid waste. At SNL/CA burned out light tubes are replaced and collected by the Lightning Technician from the Facilities Maintenance department. Tubes are placed in their original boxes and sent to a contractor for recycling. All tubes that are broken are managed as hazardous waste by the Waste Management department.

\subsubsection{Mercury}

Mercury is a hazardous chemical that occurs naturally in the environment and is also used in industrial applications. Properties of mercury include high conductivity and liquidity at room temperature. These properties make mercury a useful component in batteries, electrical switches, thermostats, lightning, thermometers, medical, testing and other electrical equipment. At SNL/CA this waste stream is managed by Waste Management program. All waste mercury is recycled by a waste transportation, storage and disposal contractor. 


\section{2 .13 Oil}

Used motor oil is considered a hazardous waste in the State of California and disposing of it in the trash, on the ground, or in the sewer is illegal. Waste oil at SNL/CA is mainly generated by the maintenance of heavy equipment, and carts, and for the servicing of mechanical pumps. Waste oil is collected and managed by the Waste Management program. The oil is sent to a contracted treatment, storage and disposal company where it is filtered for re-blending. Small lab pack quantities of used oil are disposed as hazardous waste.

\subsubsection{Oil Filters}

Oil filters are considered a hazardous waste by the State of California due to the significant amounts of oil contained in a used filter. Filters at SNL/CA are primarily generated by the maintenance of utility carts, heavy equipment and pumps. Filters are drained and managed by the Waste Management program and sent to a contract recycler. Site oil recovery systems have been deemed cost prohibitive due to the amounts of filters collected.

\subsubsection{Paper}

Recycling containers are placed around the SNL/CA site for paper collection. These containers are emptied twice a week by the janitorial staff and placed into specific bins. Each week an escorted Contractor comes onsite to collect, shred and transport the shredded paper to a local recycler.

\subsubsection{Resins}

An Ion exchange bed column system is used as part of plating lab operations in Bldg. 910 . Wastewater from plating operations is filtered through this system to remove copper prior to being sent to the building Liquid Effluent Control (LEC) system. Spent resin bottles are routinely changed out and sent to a contractor for recycling. The Waste Management program assists with the manifesting, labeling and data reporting into the WIMS. Other similar applications onsite are used for water purification and are management in the same fashion.

\subsubsection{Tires}

Sandia has over 250 bicycles and over 180 utility carts that generate waste tires. Due to the large amounts of illegally dumped or stockpiled tires the State of California recognized the need for a waste tire management program. Any business that generates over 10 tires is mandated to participate in this program. Waste tires from the site motor pool are replaced offsite and the contracted tire company is responsible for the recycling of those tires. Cart and bicycle tires that are provided for recycling or disposal are tracked through a Tire Manifest System. Tires are collected and stored at the bicycle shop and are manifested for shipment when appropriate. The P2 Coordinator keeps all records for this program. 


\subsubsection{Toner Cartridges}

Toner cartridges at SNL/CA are collected daily by the Shipping and Receiving team and stored in the receiving warehouse. The contracted recycling company collects the used cartridges monthly and provides the P2 Coordinator with a cartridge count. The cartridge are cleaned, repaired and refilled for resale.

\subsubsection{Wood}

Scrap wood such as, crates and pallets are collected at the Site and transported to the local Landfill. Once there the wood is chipped and sold as mulch. The feasibility of an onsite wood chipper is being investigated.

\subsection{Landfill Waste}

Landfill waste at SNL/CA is managed by the Maintenance department. The following items are transported to the local permitted landfill.

- $\operatorname{trash}$

- green waste ( grass clippings, landscaping debris)

- mixed loads ( green waste/boxes and miscellaneous wood)

Waste Minimization opportunities for these waste streams have been evaluated and are part of the EMS goals.

Figure 1 Landfill Waste

\section{Landfill Waste}

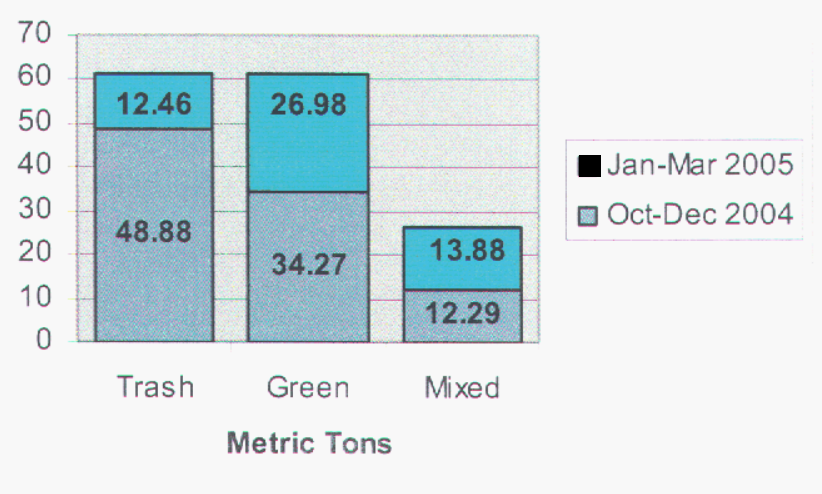




\subsection{Pollution Prevention Opportunity Assessments (PPOA)}

A PPOA is a formal source reduction evaluation aimed at identifying strategies and technologies to reduce routinely generated waste and consumption of energy and water. The assessment includes an analysis of past and recurring waste streams, a process flowchart, an evaluation of chemical use, Return on Investment calculations, and implementation options. Implementation options and strategies are dependent on availability of funding. The PPOA Team from Sandia, New Mexico provides support for this function with assistance from SNL/CA. One to two PPOAs have been completed each year for the past three years.

\subsection{Affirmative Procurement (AP)}

Affirmative Procurement is the policy and practice of purchasing products made with recycled materials instead of buying competing products made totally from virgin materials. Affirmative Procurement also includes environmentally preferable purchasing, which is the practice of considering all environmental impacts of a product prior to purchasing. Practicing AP creates recycling markets, conserves resources, saves, energy, saves landfill space, and reduces pollution. SNL/CA is committed to reaching the Energy Secretary's goal of $100 \%$ of justified purchases.

SNL/CA has supported this goal by:

- communicating with the site on AP through the use of poster campaigns, site announcements and publications.

- placing AP information on the site Staples electronic ordering database.

- blocking the use of virgin copier and printing paper in the procurement process.

- informing procurement buyers on alternative and emerging AP products

- establishing EMS AP goals

- conducting awareness training with key organizations that buy select products

- establishing a new P2 Web Page

The following graph indicates the growth of justified purchases for the last two years.

Figure 2 Affirmative Procurement

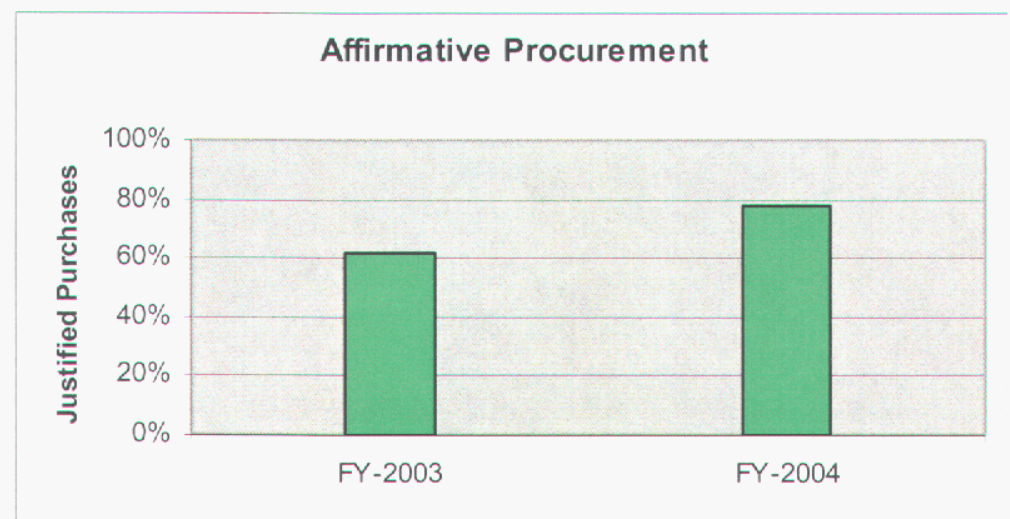




\subsection{State of California SB-14}

Sandia National Laboratories/California is required by the State of California legislation SB-14 to complete a Source Reduction and Evaluation Review and Plan. SB-14 requires generators to look at their waste generating processes and identify source reduction opportunities. Source reduction is preferable over recycling and treatment options because source reduction avoids waste generation costs and management liability. Source reduction also provides the very best protection for public health and the environment. If more than 12,000 kilograms of hazardous waste or 12 kilograms of extremely hazardous waste are routinely generated during the reporting year, then source reduction planning is required.

Each generator regulated under the legislation is required to conduct a source reduction evaluation review and plan every four years and the plan must be available upon request. The state approved a single multi-site plan that encompasses multiple DOE facilities including Sandia National Laboratories/California (SNL/CA), Lawrence Livermore National Laboratory (LLNL), Lawrence Berkeley National Laboratory (LBNL), and Stanford Linear Accelerator Center (SLAC). DOE Oakland oversees data collection, the final report and submittal of the final report to the Department of Toxics Substance Control in Sacramento, California. The previous plan submitted to the State was completed August 31, 2003. The next Source Reduction and Evaluation Review and Plan is due September 01, 2007.

Each DOE site is responsible to prepare the data for the report that includes the amount of hazardous waste generated at each site to identify the major waste streams. Waste streams consisting of $5 \%$ or more of routine waste are identified. This plan also includes a Hazardous Waste Management Performance Report and a Summary Progress Report.

\subsection{Waste Information Management System (WIMS)}

The Waste Information Management System (WIMS) is a corporate database that tracks hazardous waste from cradle to grave. WIMS is required to be used whenever hazardous waste is generated. The P2 Coordinator works closely with the Waste Management program to assure that each piece of hazardous waste is correctly classified. Its data is also used for pollution prevention data reporting and for reviewing, changing, and approving P2 categories weekly. Routinely generated waste streams are from ongoing processes and operations and from regularly scheduled maintenance. Non-routinely generated wastes are from spills, restoration activities and one time events such as laboratory chemical clean outs. The P2 categories are as follows:

Table 1. P2 Reporting Categories

\begin{tabular}{|c|c|}
\hline Tosca-routine & Tosca non-routine \\
\hline RCRA-routine & RCRA-non-routine \\
\hline Non-RCRA-routine & Non-RCRA-non-routine \\
\hline Recycle-routine & Recycle-non-routine \\
\hline
\end{tabular}

Selecting the correct category of $\mathrm{P} 2$ is imperative for data evaluation and reporting requirements. 


\section{$1.8 \quad$ Reporting}

Compiling waste generation data (solid and hazardous), recycling data, and accomplishments though out the year is a Federal and DOE requirement and an integral part of the P2 program. Hazardous waste generation data and certain categories of recycled waste information are extracted from WIMS. Other recycling data and solid waste data are collected throughout the year from various delivery receipts, sales slips, and tipping invoices.

\subsection{Treatment}

Treatment of hazardous waste at the California Site is prohibited except at those locations which are authorized through California's tiered permitting process. The following SNL/CA locations hold permits to treat hazardous waste by neutralization and $\mathrm{pH}$ adjustment:

- Sanitary Sewer

- Main LEC Tank-Building 910

- Batch Treatment System-Building 910 Room 310

- Neutralization System- Building 968 Room120

Building 9611, the Hazardous Waste Storage Facility, is authorized by a Part B Permit to comingle waste and crush empty containers.

\subsection{Disposal}

Disposal of hazardous waste at the California site is managed by the Waste Management program using a contracted disposal company: Teris, N.A. in El Dorado, Arkansas.

\section{Figure 3 Routine Hazardous Waste}

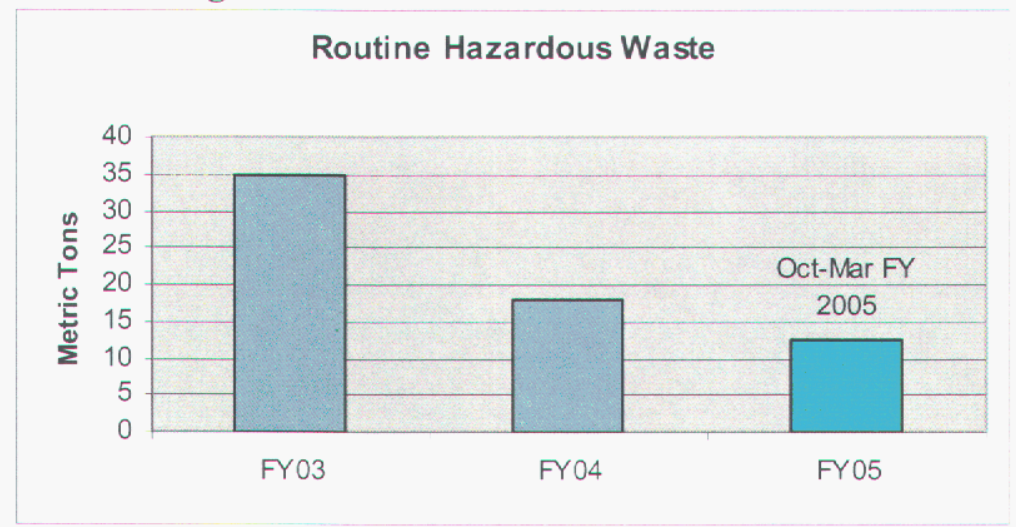




\section{Regulatory / Corporate Drivers}

The primary drivers for the Pollution Prevention Program are the Pollution Prevention Act of 1990 and the Resource Conservation Recovery Act (RCRA). These drivers require that Sandia have a pollution prevention program in place. There are Executive Orders, DOE Orders and a Senate Bill regulating the Pollution Prevention Program. Additionally, the ES\&H Manual and it's supplement "GN470075, Guidelines for Waste Generators at SNL/CA." provides direction to SNL/CA for waste generation and pollution prevention. Operation Procedures OP471811 and OP 472168 outline the responsibilities for Pollution Prevention for recycling Freon and the Biannual Site Clean up.

\section{$2.1 \quad$ Federal Regulations}

2.1.1 The Pollution Prevention Act of 1990 establishes a national policy for pollution prevention, and introduces what is known as the pollution prevention hierarchy. The hierarchy requires facilities to prevent pollution prevention at the source whenever feasible, followed by reuse/recycle, then treatment, and disposal.

2.1.2 Resource Conservation Recovery Act (RCRA) establishes a cradle to grave management framework and a regulatory system for solid waste. Waste generators must have a waste minimization program in place that reduces volume and toxicity of waste. Another section of the Act requires procurement of products that container recycled-content or recovered materials.

2.1.3 The Clean Water Act requires industrial storm water discharge facilities to have an onsite pollution prevention plan... It also directs the EPA to promote the inclusion of pollution prevention technologies in industrial effluent standards and promote source reduction in industrial water effluent guidelines.

2.1.4 The Clean Air Act directs EPA to consider pollution prevention technologies when selecting Maximum Achievable Control Technologies (MACT) for sources of Air Pollutants.

2.1.5 The Energy Policy Act of 1992 requires the Secretary of Energy to work with federal agencies to significantly reduce the use of energy related to environmental impacts, by promoting energy use efficiency and the use of renewable energy technologies.

\section{$2.2 \quad$ Executive Orders}

2.2.1 Executive Order 12088, Federal Compliance with Pollution Control Standards makes the head of each Federal Agency responsible for the prevention of environmental pollution at Federal facilities and as well as for all activities that are under the control of that agency. 
2.2.2 Executive Order 12856, Federal Compliance with Right-to-know Laws and Pollution prevention requires Federal agencies to reduce toxins entering waste streams and release to the environment through source reduction; to report toxic-chemicals entering the waste stream and releases to the environment; to improve emergency planning, response, and accident notification; to encourage markets for clean technologies and safe alternative to hazardous substance and toxic-chemicals; and to set waste reduction goals.

2.2.3 Executive Order 12843, Procurement Requirements and Policies for Federal Agencies for Ozone-Depleting Substances, requires Federal agencies to develop programs to minimize procurement of materials and substances that contribute to the depletion of stratospheric ozone. These programs include giving preference to the procurement of chemicals; produces and manufacturing process that reduce overall risk to human health and the environment buy lessening depletion of stratospheric ozone. (LEE).

2.2.4 Executive Order 13101, Green the Government through Waste Prevention, Recycling and Federal Acquisition reinforces RCRA 6002 by expanding and strengthening the federal government's commitment to recycling and buying recycled content and environmentally preferable products and services. The Executive Order state the federal agencies are to make more efficient use of natural resources by maximizing recycling and prevention waste whenever possible.

2.2.5 Executive Order 13123, Greening the Government through Efficient Energy Management establishes goals for reducing greenhouse gases improving energy efficiency, reducing energy consumption, expanding the use of renewable energy facilities, reducing use of petroleum, and reducing water consumption.

2.2.6 Executive Order 13148 Greening the Government through Leadership in Environmental Management, requires federal agencies to develop environmental management systems, use pollution prevention as a means to achieve and maintain compliance, establish goals for reducing toxic, hazardous and ozone-depleting chemicals use, and promote environmentally beneficial landscaping.

2.2.7 Executive Order 13149 Greening the Government through Federal Fleet and Transportation requires Federal agencies to use alternative fuels, and to reduce petroleum consumption through improvements in fleet fuel efficiency and through the use of alternatively fuel vehicles.

\subsection{Department of Energy Requirements}

2.3.1 DOE Order 4700.1, Project Management establishes the project management system that DOE design projects must follow. It includes numerous pollution prevention concepts and requirements. This order limits contamination of facilities, provides design features that ease decontamination, and incorporates features that promote the reuse of facilities. 
Pollution Prevention Program

June 2005

2.3.2 DOE Order 413.3, Program and Project Management for the Acquisition of Capital Assets establish the general requirements for capital assets, and include numerous pollution prevention and sustainable design concepts and requirements.

2.3.3 DOE Order 430.2A Departmental Energy and Utilities Management, establishes energy requirements as described in EO 13123 and includes requirements to reduce energy consumption, green house gas emissions and use of renewable resources. This order requires the application of sustainable design principles to new buildings and building alterations, and the submission of a Sustainable Design Report.

2.3.4 DOE Order 435.1, Radioactive Waste Management requires waste minimization and pollution prevention to be implemented at all facilities that manage radioactive waste.

2.3.5 DOE Order 450.1 Environmental Protection Program requires implementation of sound stewardship practices that are protective of air, water, land, cultural and ecological resources impacted by DOE operations and by which DOE meets or exceeds compliance with applicable environmental, public health, and resource protection laws, regulations, and DOE requirements in a cost-effective way.

\subsection{State of California Requirements}

2.4.1 Hazardous Waste Source Reduction Planning -- SB 14

The Hazardous Waste Source Reduction and Management Review Act of 1989, also known as Senate Bill 14, requires hazardous waste generators to seriously consider source reduction as the preferred method of managing hazardous waste. Source reduction is preferable over recycling and treatment options because source reduction avoids waste generation costs and management liability. Source reduction also provides the very best protection for public health and the environment. If you annually generate more than 12,000 kilograms of hazardous waste or 12 kilograms of extremely hazardous waste, you are required to do source reduction planning. 


\section{Operational Controls}

\subsection{Operating Procedures (OP)}

Operating Procedures (OP) are technical work documents that define and inform personnel of the operations and procedures associated with their work. The OP process can originate by the competition of a preliminary hazard screening (PHS) but OPs can be generated that are not a result of a PHS process. The P2 Program Lead consults on OPs related to the generation of waste or pollution prevention. This consultation allows the opportunity to communicate P2 requirements, goals, issues and concerns into procedures.

\subsection{Interdisciplinary Team Review (IDT)}

The IDT consists of subject matter experts from all ES\&H disciplines as well as representatives from security and communications. The Department of Energy site representative also participates. The IDT reviews projects and actions proposed by researchers, facility staff and program managers to evaluate environmental, safety and health hazards and define methods to control them. The process meets the ISMS-EMS criteria to "plan work", "analyze hazards", "control hazards", "Feedback \& Improvement."

IDT reviews help the $\mathrm{P} 2$ program by allowing $\mathrm{P} 2$ goals and objectives to be factored into proposed site projects and actions prior to execution. Many times alternatives will be discussed and decided that results in the prevention or reduction of waste generation. 


\section{Documents Produced}

Table 2 below identifies the required documents and reports that are produced for the Pollution Prevention program.

Table 2 Pollution Prevention program documents and reports.

\begin{tabular}{|c|c|c|c|c|}
\hline Document & Due Date & $\begin{array}{l}\text { Frequency of } \\
\text { Distribution }\end{array}$ & Distribution & Purpose \\
\hline $\begin{array}{l}\text { Waste Minimization Certification: Certifies } \\
\text { P2 Program is in place }\end{array}$ & March 01 & Annual & $\begin{array}{l}\text { Department of } \\
\text { Toxic Substance } \\
\text { Control }\end{array}$ & $\begin{array}{l}\text { State } \\
\text { requirement }\end{array}$ \\
\hline $\begin{array}{l}\text { Annual Waste Generation and Pollution } \\
\text { Prevention Progress Report: Provides waste } \\
\text { generation data, recycling data, and } \\
\text { accomplishments }\end{array}$ & November & Annual & DOE/SSO & $\begin{array}{l}\mathrm{DOE} \\
\text { requirement }\end{array}$ \\
\hline $\begin{array}{l}\text { Affirmative Procurement Report: Provides } \\
\text { data for AP purchases including successes } \\
\text { and failures }\end{array}$ & December 31 & Annual & $\mathrm{DOE} / \mathrm{SSO}$ & $\begin{array}{l}\text { DOE } \\
\text { requirement }\end{array}$ \\
\hline $\begin{array}{l}\text { Annual Site Environmental Report } \\
\text { (ACER):Summary of environmental } \\
\text { compliance, program, and monitoring } \\
\text { activities }\end{array}$ & February 01 & Annual & $\begin{array}{l}\text { Unlimited public } \\
\text { release }\end{array}$ & $\begin{array}{l}\mathrm{DOE} \\
\text { requirement }\end{array}$ \\
\hline $\begin{array}{l}\text { Environmental Scorecard: Provides } \\
\text { highlights of environmental program actions }\end{array}$ & $\begin{array}{l}\text { Quarterly-10 } \\
\text { days after the } \\
\text { end of the } \\
\text { Quarter }\end{array}$ & Quarterly & $\begin{array}{l}\text { SNL/CA } \\
\text { Director, Mgrs, } \\
\text { SNL/NM } \\
\text { Environmental } \\
\text { Mgrs }\end{array}$ & Information \\
\hline $\begin{array}{l}\text { Quarterly Reporting: Provides highlights of } \\
\text { environmental program actions }\end{array}$ & $\begin{array}{l}\text { Quarterly-10 } \\
\text { days after the } \\
\text { end of the } \\
\text { Quarter }\end{array}$ & Quarterly & $\begin{array}{l}\text { ES\& H } \\
\text { Assurance, Dept. }\end{array}$ & Information \\
\hline $\begin{array}{l}\text { Source Reduction and Evaluation Review } \\
\text { and Plan (SB-14) }\end{array}$ & $\begin{array}{l}\text { September } \\
01,2007\end{array}$ & Every 4 years & $\begin{array}{l}\text { Department of } \\
\text { Toxic Substance } \\
\text { Control }\end{array}$ & $\begin{array}{l}\text { DOE } \\
\text { requirement }\end{array}$ \\
\hline
\end{tabular}




\section{Approved Job Descriptions, Qualifications \& Training}

The Pollution Prevention staff consists of two Co-Program Leads and relies on the Maintenance and Reclamation staff for materials pick up and data collections. Pollution Prevention personnel must have knowledge of the Sandia corporate Pollution Prevention Program and be well versed in associated regulatory drivers. Training for Pollution Prevention personnel at SNL/CA includes a working knowledge of the Waste Management program.

Table 3 Required Staff Training

\begin{tabular}{|c|c|c|c|c|}
\hline Training Requirement & $\begin{array}{l}\text { Training } \\
\text { Method }\end{array}$ & $\begin{array}{l}\text { Program Lead- } \\
\text { Technologist }\end{array}$ & $\begin{array}{c}\text { Program } \\
\text { Lean } \\
\text { Staff } \\
\text { Member } \\
\end{array}$ & Frequency \\
\hline Pollution Prevention Workshops & Offsite & - & ! & When Available \\
\hline E2P2 Teleconferences & Onsite & - & - & Quarterly \\
\hline Program Workshops-seminars & Offsite & - & - & When Available \\
\hline HAZWOPER: 8-hour refresher & Online-Offsite & - & - & Annual \\
\hline Blood Borne Pathogens (MED113) & Sandia class & - & & Annual \\
\hline Emergency Preparedness (ESH 100) & Web based & - & - & Annual \\
\hline ES\&H Rights (ESH 100) & Web based & - & - & Annual \\
\hline Fire Extinguisher Awareness (ESH 100) & Web based & - & - & Annual \\
\hline Lock/Tag Out Awareness (ESH 100) & Web based & 匹 & - & Annual \\
\hline $\begin{array}{l}\text { Spill Prevention Control/Countermeasures } \\
\text { (ENV 203a) }\end{array}$ & Web based & - & & Biennial \\
\hline Respiratory Protection for Users (RSP 215) & LLNL & - & & Annual \\
\hline Title 22/RCRA Compliance Course & Offsite & 匹 & 匹 & Annual \\
\hline Fire Extinguisher Hands On (FRP 106) & Sandia Class & $\square$ & - & Annual \\
\hline Forklift: Operation Refresher (FKL 153R) & Sandia class & - & & Triennial \\
\hline $\begin{array}{l}\text { DOT: General Awareness and Function } \\
\text { Specific }\end{array}$ & Offsite & - & - & Triennial \\
\hline $\begin{array}{l}\text { Radioactive \& Mixed Waste } \\
\text { Training/Generators (ENV 233) }\end{array}$ & Web based & - & - & Biennial \\
\hline Radworker Training (RAD 230) & $\begin{array}{l}\text { Sandia class } \\
\text { w/ practical }\end{array}$ & - & - & Biennial \\
\hline Heart Saver CPR \& First Aid (MED 104C) & Sandia class & - & & Biennial \\
\hline $\begin{array}{l}\text { Hazmat Transportation Security Awareness } \\
\text { (HM 232) }\end{array}$ & Offsite & - & & Triennial \\
\hline Confined Space Awareness (CNF105) & Sandia class & - & & Triennial \\
\hline Forklift: Hands on Use (FKL 153) & Sandia class & - & & One time only \\
\hline Radiation Safety Orientation ( $\operatorname{Rad} 102$ ) & Sandia class & * & $*$ & $\begin{array}{l}\text { Not required if } \\
\operatorname{Rad} 230 \text { is taken }\end{array}$ \\
\hline HAZWOPER: 40 hour & Offsite & - & - & One time only \\
\hline Three Day Supervised Training & Offsite & - & - & One time only \\
\hline
\end{tabular}




\section{Performance Measures}

SNL has developed specific performance metrics based on the DOE Secretary of Energy's Pollution Prevention and Energy Efficiency (P2/E2) Leadership Goals for 2005 and Beyond (November 12, 1999). The P2 goals have been incorporated into DOE Order 450.1 and the E2 goals have been incorporated into DOE Order 430.2A. In some cases the SNL performance metrics differ from the DOE goals because of SNL's specific mission and planned work scope. New Mexico and California waste generation and recycling data is reported to DOE by corporation rather than by Site. At the present time, new performance measures are being proposed by DOE Headquarters. These performance measures will be refined to form the basis of the P2 tracking and reporting system for 2006 and beyond and, subsequently, development of the annual Greening the Government progress reports.

\section{Quality Assurance}

Pollution Prevention uses the following methods to assure quality is maintained in data collection, analyses, and reporting:

- Internal reports and documents are reviewed internally for accuracy.

- Waste Generations/Recycling data is captured by WIMS and data is checked with Waste Management reports.

- Sanitary Waste data is matched to invoices and or verbal verification is received by Landfill staff.

- Affirmative Procurement data is reviewed and checked against the Staples electronic ordering system, catalog or suppliers.

- Budget \& Reporting numbers are matched against the Budget \& Reporting DOE Database.

- The Waste Minimization Certification is reviewed prior to submittal.

\section{Program Assessments}

The Pollution Prevention program is informally assessed annually by the DOE Service Center located in New Mexico with participation from the Sandia Site Office. The Department of Toxic Substances Control, California, audits Waste Management and Pollution Prevention yearly. The $\mathrm{P} 2$ portion of the DTSC audit consists of a review of affirmative procurement practices, training, the Waste Minimization Certificate, SB-14, and training as required by the Part B Permit.

In 2005, the Pollution Prevention program will complete a program self assessments. The assessment will include a review of documentation, and processes as well as P2 awareness and line implementation. 


\section{Accomplishments}

\subsection{P2 Awareness}

Effective communication is key to a successful Pollution Prevention program. In the past year the following information has been distributed to communicate P2 Goals and objectives.

- EMS Fact Sheets presented

- EMS survey completed

- Affirmative Procurement information balloon

- Affirmative Procurement posters distributed

- National Pollution Prevention Week tidbits
- Training updated

- Personal memos distributed

- New P2 Web page

- SHEAC EMS presentation

- Earth Day

\section{$9.2 \quad$ Earth Day}

Earth Expo 2005 was an activity held jointly on April $20^{\text {th }}$ with LLNL. Posters and banners were

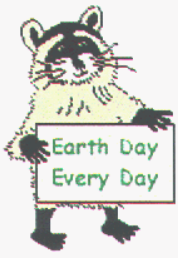
placed around the Site a month prior to help kick off the event. Over 50 invitations were sent out to various agencies through out the Bay Area asking for their participation. Sandia booths showcasing The Environmental Management System (EMS), the Hazardous Waste Storage Facility and our Wildlife Biology Program were highlights for the day. Information on composting, and the Federal Electronics Challenge were handed out, and Presentations by the Livermore Water Board, Earth Share and the California Integrated Waste Management Board were just a few of the other participants.

\subsection{Bi-annual Site Clean Up}

A new site cleanup program was started during the past year to beautify the site and remove excess equipment, furniture and trash. The Site Zone Manager coordinated this effort and during this six week campaign the materials were staged, evaluated, and sorted by the Zone Manager, Reapplications and Property Team and Pollution Prevention Coordinator. Many items were reapplied to other members of the workforce.

\subsection{Electric Car Demonstration}

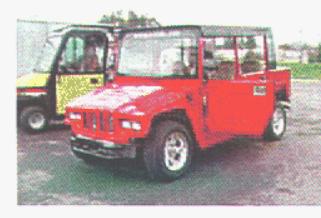

Used for daily operations, the California site has over 150, 4-wheeled utility carts on the Site. These carts, some electric, but mostly gasoline powered, are used mainly by the Maintenance Department for transporting tools, equipment and products for their daily work around the 410 -acre Site. The Site is encouraged to replace old gasoline powered carts when funding becomes available. The P2 Coordinator organized an electric cart demonstration by E-ride Industries of Minnesota. The Demonstration was communicated in the Sandia Daily News (TNT) and approximately thirty members of the work force took test drives. 


\subsection{Reports and Documentation}

Compiling waste generation data (solid and hazardous), recycling data, and accomplishments throughout the year are an integral part of the Pollution Prevention Program. As required, the following documents were submitted on time to their proper destinations:

Waste Minimization Certification

Annual Waste Generation and Pollution Prevention Progress Report

Affirmative Procurement Report

Annual Site Environmental Report (data provided)

Environmental Scorecard (data provided)

Quarterly Reporting and Accomplishments

\subsection{New Recycling Program}

The Paper Recycling Pilot Program was a big success and went site-wide in March of 2005. Each office was delivered a new recycle bin and members of the workforce were provided training. This new program is much easier for the Site, safeguards our information, and has greatly increased the amount of paper sent to the Recycler.

\subsection{Laboratory Dismantle}

Due to a change in mission and completion of the program, the Extreme Ultraviolet Lithography (EUVL) laboratory was dismantled. The EUVL laboratory consisted of a high-bay area of approximately 13,000 $\mathrm{ft}^{2}$. Members of the work force and LLNL were notified of equipment availability. Equipment such as lasers, optical tables, clean rooms and their supplies were reclaimed. The P2 Coordinator, the Reapplication and Property Team, and a student intern evaluated equipment for reuse, collected property accountability numbers, sorted furniture and disposed of scrap metals and trash. All items were cataloged for funding accountability. It is estimated that 3 million dollars of materials were reclaimed. The P2 Coordinator is investigating a better way to collect the quantitative data.

\subsection{Empty Container Recycling}

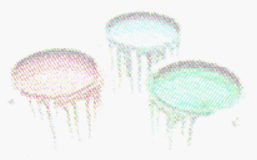

The Empty Container Recycling program was a big success and is now being used site-wide. Members of the work force who use chemicals, now have the opportunity to collect and mark their containers for recycling. Previously these containers were managed as hazardous waste. This is a great P2 opportunity that saves hazardous waste generation and costs.

\section{$9.9 \quad$ Interdisciplinary Team (IDT) Reviews}

Pollution Prevention reviewed 71 projects from October 2004 and March 2005. Information regarding EMS goals and objectives have been routinely given to presenters since April 2005. 


\section{Trends}

New regulations have changed in the past two years that affect the Pollution Prevention program, including DOE order 450.1 Environmental Protection Program. The objective of this Order is to implement sound stewardship practices that are protective of air, water, land, and other natural and cultural resources impacted by DOE operations. It also requires that an Environmental Management System (EMS) be implemented that include measurable P2 objectives and goals. This new Order supersedes DOE Order 5400.1 General Environmental Protection Program.

A second change to the $\mathrm{P} 2$ program is the addition of the California Tire Waste Manifest System, which mandates that tires for disposal or recycle be specifically controlled. This program is managed by the California Integrated Waste Management Board.

Another change that affects the program is the Electronic Waste Recycling Act. This Act requires the specific management of electronics devices such as Cathode Ray Tubes (CRT's), desktop monitors, laptop computers with LCD displays, and televisions.

\section{Goals and Objectives}

Current general Environmental Management System (EMS) environmental goals related to the Pollution Prevention program are:

- Decrease electrical consumption per building square feet

- Reduce quantities and toxicity of hazardous materials

- Reduce quantities of hazardous waste generated

- Reduce quantity to the landfill through reduce consumption and/or recycling

- Reduce sewer water quantity and improve quality.

More specific pollution prevention related objectives \& targets and related actions for the next 13 years are:

- Reduce site hazardous material container inventory count by $10 \%$ from the baseline. (FY-2005)

- Decrease the purchases of pesticide containers by $20 \%$ from the FY04-05 average. (by end of FY-2006)

- Work with Maintenance to facilitate the purchase of items in bulk containers and transfer to reusable aerosol cans.

- Increase the amount of paper that is recycled by $20 \%$ from the FY04/05 average. (by end of FY-2006)

- Develop and execute communications to educate the site about the paper recycling program.

- Increase the purchases made by the Affirmative Procurement Program by 5\% from FY03/04/05 average. (by end of FY-2006)

- Develop and provide training for the site on the Affirmative Purchasing Program. 
- Switch all exterior security lighting to energy conserving type. (by end of FY2007)

- Meet with Security to encourage them to turn lights off after security sweeps

- Reduce the Site's routine hazardous waste quantity by $10 \%$ per capita (by end of FY2007)

- Investigate non-hazardous materials alternatives for Maintenance actions.

- Execute PPOA for maintain oils, lubricants and pesticides.

- Investigate the onsite recycling of waste oils.

- Investigate the use of alternative lubricants for maintenance vehicle fleet and equipment.

- Investigate gas dispenser nozzles with the latest technology to help prevent overfilling.

- Prepare an investment request to purchase a solvent-free Paint Gun Cleaner for painting operations.

- Increase the recycling of construction debris by 20\% of the FY04/05/06 average.

- Develop a process and implement to obtain valid recycling information from Contractors. (by end of FY2007)

- Recycle $90 \%$ of the site's wood waste

- Establish a collection point for box and crate chipping and investigate funding options for a chipper.( FY2008)

- Recycle $90 \%$ of the Site's concrete and asphalt debris (FY-2008)

- Evaluate the cost of purchasing a concrete and asphalt crusher

- Decrease building electrical usage to 26 kilo-watt-hours per gross square footage on an annual basis by the end of FY-10. Decrease metered process (laboratory buildings) usage to 200 kilo-watt-hours per gross square footage on an annual basis by the end of FY 10

- Perform public/site wide outreach to encourage reduction of electric use. 


\section{Appendix A}

\section{P2 Program Self Assessment Document Review Form}

\begin{tabular}{|l|l|l|l|}
\hline Document Type & Document Title & Review Complete & Changes Made \\
\hline Operating Procedure & & $\square$ & $\square$ Yes \\
\hline & & $\square$ & No \\
\hline PHS & & $\square$ & $\square$ No \\
\hline Other Program Documents & Annual Program Report & $\square$ & $\square$ Yes \\
\hline & & & $\square$ No \\
\hline Web Pages & & $\square$ No \\
\hline & P2 Web Pages & $\square$ & $\square$ No \\
\hline & & $\square$ & $\square$ No \\
\hline Yes \\
\hline No
\end{tabular}

Organization: $\quad 8516$

Program: Pollution Prevention

Calendar Year:

Signature: 


\section{Appendix B}

\section{Current Program Staff Assignments}

Table 1 HMM Program Assignments

\begin{tabular}{lll}
\hline Job Assignment & Personnel & Back-Up \\
\hline Program Co-Lead & Janet Harris & Laurie Farren \\
\hline Program Co-Lead & Laurie Farren & Janet Harris \\
\hline
\end{tabular}


Pollution Prevention Program

June 2005

\section{Distribution}

3 MS 9221 Laurie J. Farren

3 MS 9018 Central Technical Files, 8945-1

1 MS 0899 Technical Library, 9616

1 MS 9021 Classification Office, 8511 for Technical Library, MS 0899, 9616 DOE/OSTI via URL 